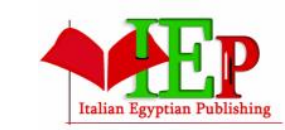

ISSN: 2785-9673

INTERNATIONAL JOURNAL OF

ARCHITECTURAL ENGINEERING AND URBAN

RESEARCH

VOLUME 3, ISSUE 2, 2020, $62-80$.

www.egyptfuture.org/ojs/

\title{
Method to Assess Historic Palaces Rehabilitation Projects
}

\author{
Yasmine Sabry Mahmoud a, *
}

a Lecturer, Faculty of Engineering, Zagazig University

\begin{abstract}
In the English language; a buffer zone is an area that separates two other areas. In this research, we hint to the main role of a buffer zone in preserving heritage with universal value through organizing the means of dealing with the surroundings of its historic area. For example, the visual impact of high rise buildings within the buffer zone needs to be considered; as well as the reflection of legislations and rules of management on the borders and boundaries of the site. This is in addition to the pressure of urban development, and the most stressing problem; the land use between sole heritage and combatable activities; while these activities may be welcome to the site when suiting the value of cultural heritage. To insure the protection of the heritage site, unplanned tourism of the surroundings should be eliminated. If a buffer zone is considered a means of protection for the site, then it was mainly meant to be a management tool. It's supposed to be a first defense line in front of the heritage site to make sure the management plan is effectively implemented. Heritage values should be stated in order to clarify which activities happening in the buffer zone may harm the heritage values, so as to avoid them; especially when these activities might destroy the built fabric. We need to make it clear what is allowed and what is not. However, a problem may strongly arise if the buffer zone is not stated on the national law of its country; as in the case here; in Egypt. If the buffer was meant to act like as means of protection, it already needs to be protected in the first place to perform its duty. In this research, the experimental approach is adopted through cluster analysis in addition to logistic regression. The final outcome of this research is an assessment of buffer zones by arranging priorities of intervention.
\end{abstract}

\begin{tabular}{ll}
\hline Keywords \\
- & Buffer Zone \\
- & Multi Land Use \\
$-\quad$ & Development \\
$-\quad$ & Heritage \\
$-\quad$ & Management \\
\hline
\end{tabular}

\section{Introduction}

The idea of the buffer zones started from the central parts of cities; where kings' palaces were surrounded by those of the lords in arranged hierarchy. This surrounding area was defined as a zone protected from the evil; a buffer zone ${ }^{1}$. The more we got far from the center of the city, the less inhabitants were found 
and the more distant were the buildings from the core monumental area. From the concept of a sacred city surroundings, the idea developed to define a buffer zone as an area that was kept to separate two other areas, or alternatively to let the two areas integrate.

Monuments and historic districts work as core zones which are surrounded by buffer zones; which in turn need more than a conservation approach, but rather an approach of total urban revitalization within short, medium, and long term plans. These plans should manage the means to deal with historic buildings, spaces, and infra-structures, improving buildings appearance, rehabilitation, and all architectural activities which can enhance people's quality of life. An integrated approach needs to be formulated merging social, cultural, and economicaspects. It should start with a complete diagnosis of the elements of these mentioned aspects ${ }^{2}$, while studying the interventions between heritage sites and urban context, for both the core and buffer zones. We can summarize a general diagnosis of the problems of both core andbuffer zones on a global level as follows:

- Uncontrolled mobility

- Lack of conservation for historic buildings and districts

- Multi land use within the historic district

- Unmanaged tourism

- Undefined parties' responsibilities

- Unclassified funding of development aspects

- Non-integrated sustainable development of social, cultural, and economic approaches

- Unconsidered energy consumption ${ }^{3}$

\subsection{RESEARCH PROBLEM}


Mismanagement and lack of protection for buffer zones in historic districts causing bad impact on heritage districts represented in the core zones which have deteriorated consequently.

\subsection{RESEARCH OBJECTIVE}

Using cluster analysis of variable case studies to assess Egyptian heritage buffer zonesand prioritize intervention.

\subsection{RESEARCH LIMITATION}

This research is limited to 30 districts, located in five countries, which the researcher was capable of visiting to collect data. The five countries contain huge heritage sites as in thecase of Egypt, that are inscribed on the world heritage list. The people also answering the research questionnaire were selected to have a background on world heritage management.

\section{BUFFER ZONES DIFFINITIONS AT WORLD HERITAGE CONVENTIONSAND THE OPERATIONAL GUIDELINES}

UNESCO is an international organization that issued the world heritage convention which organized the means of dealing with heritage and buffer zones. UNESCO has also highlighted the buffer zone concept many times in different publications and produced an Operational Guidelines manual to clarify many aspects connected to heritage sites and the means to deal with them. The OG manual had many editions; and had discussed the buffer zone as follows:

2.1. In OG 1977 and 1978 editions, the definition of a buffer zone starts with identifying the property surface area and the sub surface area when 
necessary, stating that a buffer zone around a property is a form of natural yet man-made surrounding that influences the physical state of the property. ${ }^{4}$

2.2. In OG 1980, 1983, 1984, and 1987 editions, it is clarified that a buffer zone should be provided with the necessary protection. Defined as an area surrounding the property which has essential influence; the buffer zone physical status is said to be necessarily determined through detailed studies considering a size and character map of boundaries. ${ }^{5}$

2.3. In OG 1988, 1992, 1994, and 1999 editions, an addition is made to state that the buffer zone as an area surrounding the property, has its own restrictions on land use; for its own protection. ${ }^{6}$

2.4. OG 2004 was a draft that was never published. It stated that in order to provide protection of property, an integration between the heritage district and buffer zone in a coherent management system was necessary, along a clear delineation of boundaries. Thegoal was to protect the property from the direct effect of encroachment and the impact of outside resource uses; where a legal or customary restriction on usage and development must be set to include:

- Clear delineation of the boundaries

- Buffer zone suitability to protect the heritage site from outside uses

- Existence of legal restrictions on the usage and development factors ${ }^{7}$

2.5. In OG 2005:2008, it was clearly stated that the boundaries of the property should include sufficient area attached directly with the core heritage site to protect it from impact ofoutside uses. It also mentioned that an area of protection may contain several management zones. This edition defined the buffer zone as an area surrounding the core nominated area or the cultural property, and stated that it has legal restrictions on usage and development. It 
also provided appropriate determination of buffer zone aspects; namely: mechanism, size, character, authorized use, and a map indicating the precise boundaries for both the core and buffer zones. ${ }^{8}$

\section{BUFFER ZONES AND ADVISORY BODIES}

The International Council on Monuments and Sites, ICOMOS, is the UNESCO consultant of cultural heritage, and as a consultant, ICOMOS participated in enhancing the perception of the buffer zone concept. Since ICOMOS also acts as a secretarial center for UNESCO concerning world heritage, it is responsible for implementing the modifications inthe operational guidelines. In 2005, ICOMOS held its general assembly in Xi'an, China, where a declaration was made as a result. This declaration focused on two main points for improving the definition of the buffer zone:

- First: It is not a zone of secondary importance; just to support a zone of primary importance but it rather has a complimentary role for the primary zone; which helps indefining the character and significance of the universal value of the primary zone it protects.

- Second: Other aspects of the buffer zone must be considered, beyond its physical andvisual aspects, including social, economic, and cultural aspects and the entire connected intangible heritage with the core zone.

An important review later done by ICOMOS consisted of 12 questions, of which the answerscan formulate the buffer zone management framework. These questions were:

- What are the values of the heritage property? And how does the buffer zone protectthem? 
- What are the threats to the site? What is the role of the buffer zone in minimizingthese threats?

- What are the activities and actions which could enhance the perception of heritagevalues?

- What should be the size of the buffer zone and how should it be established?

- What kind of restrictions should be in a place, for the buffer zone to be effective?

- What are the management and control systems for the buffer zone?

- Is the buffer zone defined in any plan with a legal status?

- Does the buffer zone have legal protection?

- Should there be a nomination for a world heritage site without a proper buffer zone?

- How should the boundaries of a buffer zone be marked on the ground?

- What should be the process for announcing a buffer zone by a state party? Whatshould be the process for nomination?

- $\quad$ Should there be two levels of a buffer zone? Areas closer to the inscribed zone, andareas beyond them?

Another group of important questions were also asked during the review meeting. Thesewere:

- Do the buffer zones respond to the dynamic changes of economic and socialdevelopment?

- Should the representation of the outstanding universal value of heritage be expressedin a universal way; respecting the cultural diversity heritage?

- What are the guidelines for protecting world heritage buffer zones, based on everyregion specification? 
- What are the legal and management frameworks and standards

for world heritageproperties?

The answers of the previous questions can effectively formulate the guidelines to bufferzones management. ICOMOS then classified what might be considered in cultural heritage buffer zones, as follows:

- Social factors: traditional land use

- Economic factors: the economic activity that the area follows

- Legal factors: any legal regulations from local to international

- Physical factors: whether it's naturally protected - such as being on a seaside

- $\quad$ Stakeholders' responsibility ${ }^{9}$

\section{LEGAL PRESPECTIVE FOR CORE AND BUFFER ZONES BETWEENLOCAL AND UNIVERSAL PROTECTION}

The core zone of heritage districts is being protected under the Egyptian law no. 117 produced in the year 1983, and modified in 2010 by the Egyptian government. This law ${ }^{10}$, known as the law of antiquities, defined heritage and monuments in its main statement as: every building or movable object produced by different civilizations or arts or religions from the prehistoric era through all history ages until 100 years of age, having a value or archeological significance of civilization aspects from the varied civilizations which had beenfounded on the Egyptian land or which Egypt had a shared history with, including natural human organic remains.

This law instructed the rules of conservation for monuments and heritage districts, especially how it was necessary to have a written approval while changing or modifying any part of the core zone or the surrounding zone in 
heritage cities. The law controlled the designfor the new buildings and their infra-structure within a certain area around the monument, butit did not deal with the area as a whole. Item 19 of the law formulated the idea of the buffer zone from the construction regulation point of view, focusing on the harmony and aesthetical image of the surrounding buildings located around heritage districts. Structures and heights were controlled around the historic context in item 21, whereas items 23 and 24 focused on historic buildings preservation and prevented making any changes or demolishment. In other items, law number 117 also identified the responsible parties, regulations, and punishments.

Other laws were also set to control all the activities connected to buffer zones; such as:

- Law no. 144 issued in 2006 (known as the law of urban harmony 1), offered a new level of protection to valuable heritage. In its first item, it was mentioned that demolishment or addition was forbidden while dealing with any valuable building. A punishment was also set in this law; stating that any demolishment or addition occurring to a valuable building can lead to jail or fines according to the level of violation.

- Law no. 119 issued in 2008 (known as the law of urban harmony 2), was set to organize urban planning, urban harmony and construction works, as well as means of conservation of real estate wealth, the identification of valuable districts, regulations submission and criteria, in addition to implementation priorities and funding resources. Item 26 of this law discussed the organizing of urban harmony for the purpose of protecting districts of valuable buildings; with a very clearly-stated punishment for any unplanned interference leading to jail or fines. ${ }^{11}$

Non of these laws made a certain regulation, to act as a reference when dealing with buffer zones or even when dealing with the core zone if it was a historic 
district. The laws deal with core and buffer zones as hosts to separate monuments. The buffer zone has no specific law, so any area that doesn't include monuments; is governed by the law of housing which is not strict enough to grant the required protection for the buffer zone which also needs a strategy of traffic reduction to be considered a primary procedure in protecting heritage districts. In parallel, all the deterioration which has already happened to core orbuffer zones need to be reversed ${ }^{12}$. An integrated approach is urgently needed between both boundaries of the core and buffer zones in terms of management and sustainable development ${ }^{13}$. When the buffer zone is clearly bordered around an area of good state of conservation and historic character such as the core zone, this core zone will actually get better protection. ${ }^{14}$

According to the operational guidelines of UNESCO, laws should give buffer zones moreadditional regulation. Egypt suffers from aggressions on the core zones, so it gets worse with the buffer zones; especially that the boundaries of core zones lack borders of the buffer zones,specifically in case of usable heritage ${ }^{15}$. Triple the effort is needed to manage dealing with buffer zones from practice, management, and conservation teams, parties and communities $^{16}$; as essential human resources. These should work under other legal and institutional resources, which are in turn governed by a management triangle consisting of planning, implementation, and monitoring. The management of buffer zones should not only be land management or community management, but also a changes management which is very challenging. ${ }^{17}$

\section{THREATS AFFECTING BUFFER ZONES}

Planning of buffer zones is needed to keep the authenticity of the historic buildings or thehistoric districts. This classification should be perfectly controlled, while enabling a good quality of life for the locals. Control and 
protection can be better achieved if the area includes one or two land uses, while if it has multi land uses; it gets complicated. Here comesthe role of laws and legal instructions, which differ from one country to another ${ }^{18}$. With the globalization movement, many problems are facing historic areas and affecting buffer zones, such as:

- The spreading of high rise buildings within historic settings

- Urban transformation as a result of changes in land use

- Heavy commercial motivation

- Blocks density and population

- Unplanned land uses ${ }^{19}$

A buffer zone can be either a negative or a positive space, according to its use and the architectural design of its buildings. If the space is shapeless and its buildings do not follow the basics of design, it's considered a negative space without a value. On the other hand, if theidentity of the historic setting was reflected on the buffer zone buildings, spaces design, and dimensions; positive outdoor spaces can be created which keep the historic core zone perfectly used and protected. This positive space can be a multi-function one, but still be protected by strict management, according to the different activities in its streets and the changes occurring to the urban fabric. The challenge in old urban districts of historic value iswhen the size of building blocks and narrowness of streets conflict with urban design theories. Sustainable development can be tough then.

Balance is needed to be achieved between cultural and socio-economic activities of the local community on the one hand, and the developmental activities on the other. The questionbecomes how to make the buffer zone elastic enough to perceive the development pressure from one side, and to protect the area from that pressure from the other ${ }^{20}$. In the historic districts of 
Egypt, the urban environment hardly exists, as most of these areas consist of narrow streets interrupted by squares and then the streets change directions with a lot of staticpoints that do not support circulation ${ }^{21}$. Many negative aspects can be documented in the Egyptian urban fabric of historic districts and these aspects obstruct the development plans for core or buffer zones.

Examples on such aspects are:

- Streets misconnection between one node and another

- Unorganized parking areas

- Disappearance of pedestrian pavements during day time to offer many activities

- Using non-durable finishing materials and the need for continuous maintenance

- Uncontrolled land use and rental

- Unsuitable typology of commercial activities

- Absence of visitor facilities ${ }^{22}$

Many threats affecting buffer zones can also be classified; such as deterioration whetherman-made or through natural disasters, and development activities, whether commercial, agricultural, or infra-structural; causing urban pressure and threatening non renewable resources such as oil and gas to serve mega projects such as electricity stations. Unplanned tourism, mismanagement, unclear boundaries, lack of conservation, lack of control on land use, the absence of institutional framework, cultural changes to awareness or miscommunications with the local communities and the overall socio-economic-national context all conflict with the outstanding universal values. ${ }^{23}$

The benefit expected from studying the case studies in this research is enhancing the buffer zone of historic Cairo. The evaluation will get 
through common threats that turned outto be existent in most of world heritage buffer zones, so they are mentioned as predominant issues and common items among buffer zones on a worldwide scale. These items can besummarized as:

- Visual impact of high rise buildings

- Legislative and management problems

- Unclear boundaries

- Urban development pressure

- Nonexistent borders of buffer zones

- Boundaries modifications

- Unsuitable activities

- Unsuitable buffer zones

- Unplanned tourism

- Destruction of built fabric ${ }^{24}$

Those points are intended to be used as indicators to measure the state of buffer zones inthe chosen case studies to reveal the weak points in the buffer zones of historic Cairo; the Egyptian world heritage site, in order to produce an assessment plan to deal with the threats.

\section{CASE STUDIES}

This research compares case studies to evaluate how buffer zones protect the areas ofcore zones. Through revealing the items causing threats on buffer zones in these case studies, we can reach an assessment for how buffer zones can be developed.

The criteria of selection for the historic sites was them being world heritage to makesure that the idea of the buffer zone is considered. These sites are:

\section{First city: Cairo, Egypt}


INTERNATIONAL JOURNAL OF

ARCHITECTURAL ENGINEERING AND URBAN

RESEARCH

- Featuring the districts of: The Citadel, Al-Moez, Al-Gamalia, Al-Fustat, Al-Darb Al-Ahmar, Tolon, Hussein, Ghoria, Magra Al-Oyoun, Al Khalifa

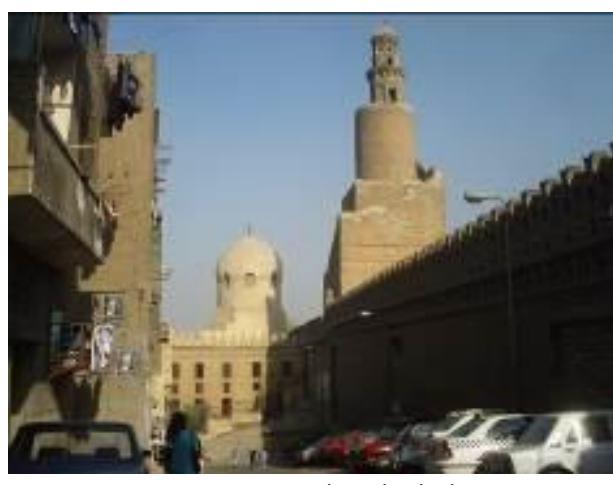

Figure 1: Al-Darb Al-Ahmar District, Cairo Moez District, CairoSource: researcher researcher

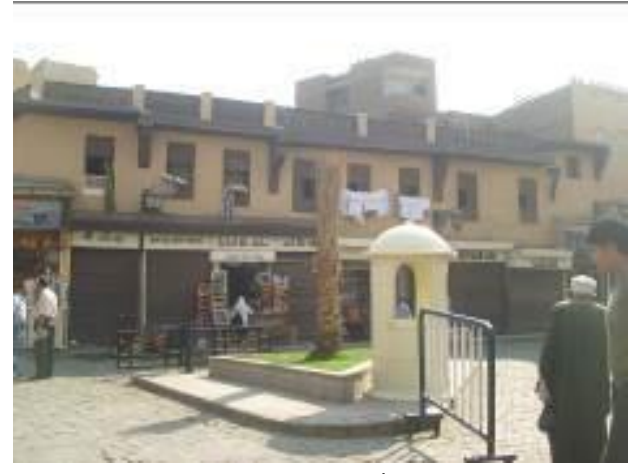

Figure 2: Al-

Source:

\section{Second city: Paris, France}

- Featuring the districts of: Champ de Mars, Eiffel tower, Le Louvre,

Grand Palace andPetit Palace, Notre Dame de Paris, Sainte Chapelle,

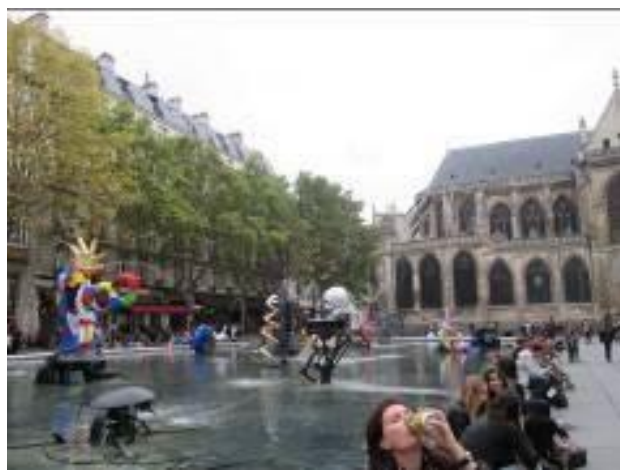

Arc De Triomphe

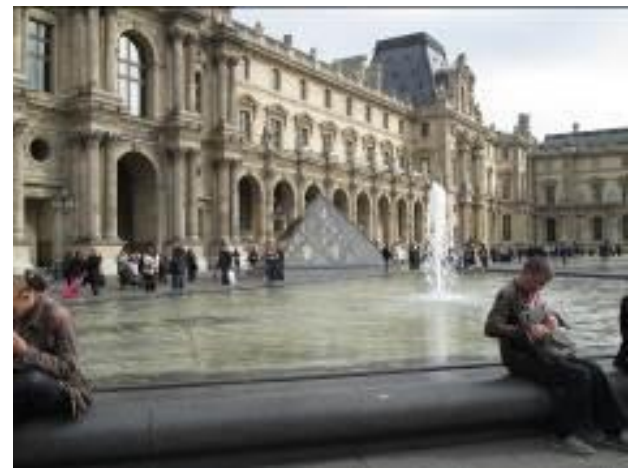

Figure 3: Stravinsky Square (Part of Notre Dame District), Paris Louvre District, ParisSource: researcher

researcher
Figure 4: Le

Source:

Third city: Barcelona, Spain 
INTERNATIONAL JOURNAL OF

ARCHITECTURAL ENGINEERING AND URBAN

RESEARCH

- Featuring the districts of: Sacred Family Church, Park Guell, Casa Mila, Palau Guell,Casa Vicens, Casa Batllo

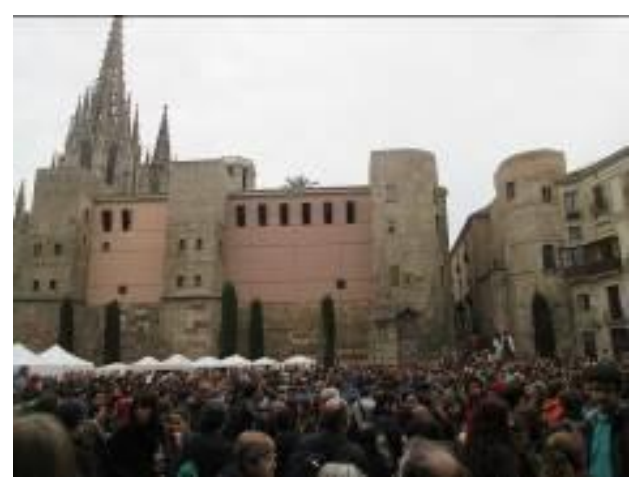

Figure 5: Works of Antoni Gaudi, Barcelona Antoni Gaudi, BarcelonaSource: researcher researcher

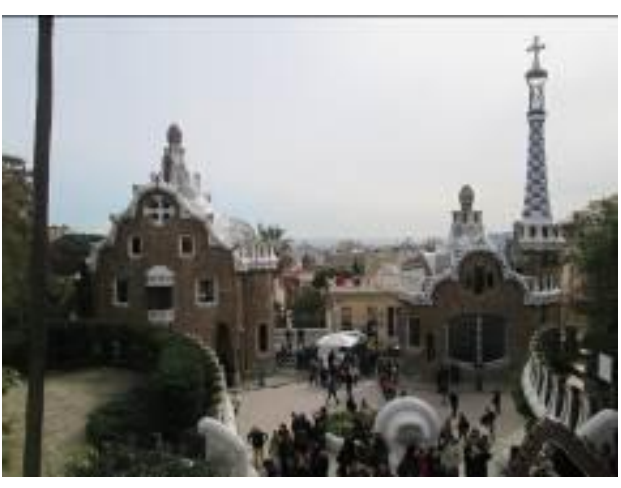

Figure 6: Works of Source:

Fourth city: Rome, Italy

- Featuring the districts of: Pantheon, Colosseum, Tragon, Trevi, Vatican, Piazza Navona

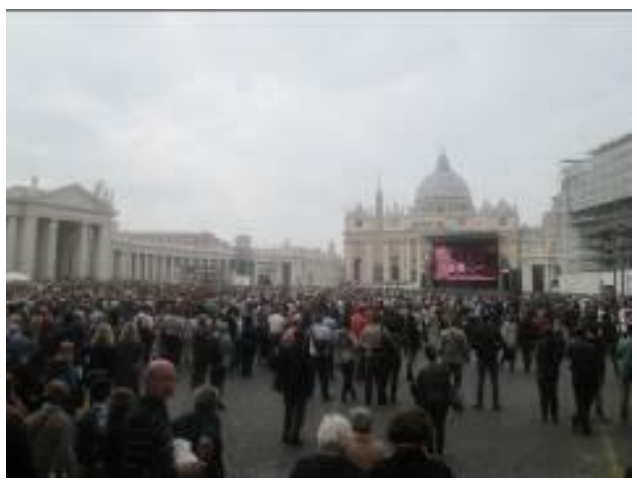

researcher

\section{Fifth city: Athens, Greece}


- Featuring the districts of: Acropolis, Acropolis Museum

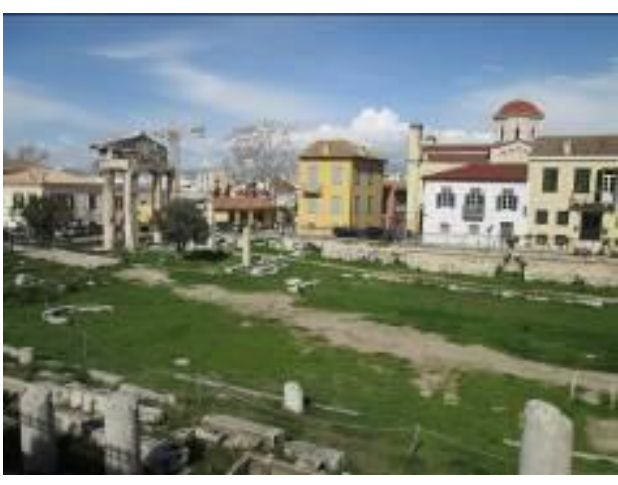

Figure 7: Acropolis district, Athens Acropolis Museum, AthensSource: researcher

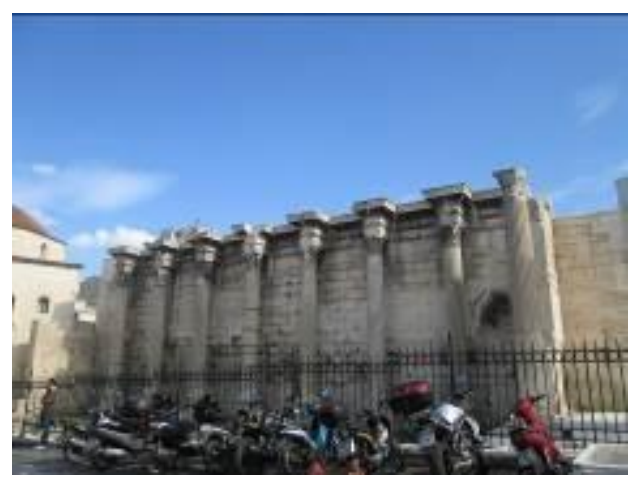

Figure 8: Historic area around Source: researcher

\section{Research Method and Material}

The research adopts a combined strategy between experimental and case study methods of research; implemented through clustering the buffer zones of different heritage districts. The zones are analysed quantitatively through 30 indicators that formulate the most common threats attached to buffer zones according to the paper of UNESCO on managing buffer zones ${ }^{25} .31$ districts at five different cities represent the case studies in the research; whereas the questionnaire acts as the main tool used for collecting data to achieve the quantitative analysis by cluster and logistic regression. 10 districts in Cairo are being compared with 21 others located in Paris, Barcelona, Rome, and Athens in order to evaluate and assess Egyptian buffer zones. The questionnaire was applied on a sample of postgraduate students in the heritage management program of the French University in Cairo. This program is the only one in Egypt that deals with heritage management within world cultural heritage sites.

\section{RESULTS}

The analysis revealed that: 
INTERNATIONAL JOURNAL OF

ARCHITECTURAL ENGINEERING AND URBAN

RESEARCH

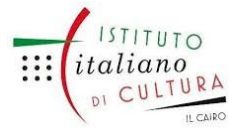

VOLUME 3, ISSUE 2, 2020, $62-80$.

www.egyptfuture.org/ojs/

- Buffer zones suffer mostly from urban pressure, unsuitable activities, and unsuitablebuffer zones

- The cluster analysis shows 3 main clusters summarized into 2

- The regression shows the priorities of intervention to assess buffer zones

\begin{tabular}{|rr|r|r|r|r|}
\hline & & & & \multicolumn{2}{c|}{$\begin{array}{c}\text { Cumulative } \\
\text { Percent }\end{array}$} \\
\hline Valid & 1.00 & 88 & 36.7 & 36.7 & 36.7 \\
& 2.00 & 152 & 63.3 & 63.3 & 100.0 \\
& Total & 240 & 100.0 & 100.0 & \\
\hline
\end{tabular}

Table 1:

Clusters

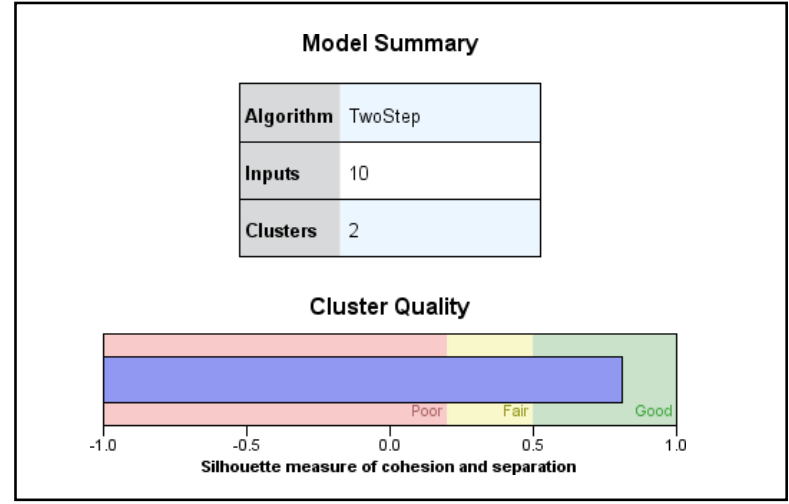

classification

Source:

researcher

Figure 9: Number of

final clusters

producedSource:

researcher 
INTERNATIONAL JOURNAL OF

ARCHITECTURAL ENGINEERING AND URBAN

RESEARCH

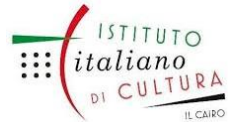

\begin{tabular}{|c|c|c|c|c|c|c|}
\hline Analysis steps & $\mathrm{B}$ & S.E. & Wald & df & Sig. & $\operatorname{Exp}(B)$ \\
\hline \multirow{2}{*}{ Step $1^{a}$} & 1.975 & .240 & 67.806 & 1 & .000 & 7.209 \\
\hline & -5.519 & .742 & 55.244 & 1 & .000 & .004 \\
\hline \multirow{3}{*}{ Step $2^{b}$} & 1.403 & .266 & 27.851 & 1 & .000 & 4.066 \\
\hline & 1.111 & .259 & 18.378 & 1 & .000 & 3.037 \\
\hline & -6.931 & 1.034 & 44.910 & 1 & .000 & .001 \\
\hline \multirow{4}{*}{ Step $3^{c}$} & .900 & .331 & 7.386 & 1 & .007 & 2.459 \\
\hline & .880 & .315 & 7.795 & 1 & .005 & 2.410 \\
\hline & 1.046 & .271 & 14.942 & 1 & .000 & 2.846 \\
\hline & -7.878 & 1.221 & 41.606 & 1 & .000 & .000 \\
\hline
\end{tabular}

Table 2: Logistic regression analysisSource: researcher

\section{DISCUSSION AND ANALYSIS}

First: Cluster Analysis: Defined as a type of data classification that is carried out byseparating the data into groups called clusters, by using variables. 31 districts were chosen forthis research; 10 of which are in Cairo, 7 in Paris, 6 in Barcelona, 6 in Rome and 2 in Athens. A cluster analysis classified the 31 districts into clusters gathering cases that resemble each other. The analysis revealed 3 clusters. Since the results of cluster analysis were very close in the $1^{\text {st }}$ and $2^{\text {nd }}$ groups of clusters, it was decided to merge them together; resulting into having 2 clusters in the analysis instead of 3 . The silhouette value obtained from the cluster analysis represented a measurement of how similar an object was to its own cluster (cohesion)compared to other clusters (separation).

Second: Logistic Regression Analysis: Defined as a statistical prediction test which can predict probability of enhancing buffer zones by interfering in certain indicators. This appearsin the column of (Exp. $\beta)$ which shows the expected $\beta$ in result of the intersection of the samples; which is considered the main point for formulating the regression analysis. In order to specify the most effective variables that affect the likelihood of belonging to the 2nd group, a 
binary logistic regression was applied, where the second group contained the 10 districts of Egypt and the 2 districts of Greece.

\section{CONCLUSION}

From the results of the variables, the analysis yielded that there are only three significant variables affecting buffer zones of historic sites: urban pressure, unsuitable activities, and unsuitable buffer zones; while the rest of the items have less importance. By prioritizing the needed intervention in Egyptian heritage buffer zones, urban pressure came first then came the unsuitable activities; which will need to be alternatively carefully chosen within physically clear buffer zone borders around heritage core zones to improve the areas which were selected to represent Egyptian heritage sites. This approach of analysis can perfectly save time by arranging intervention priorities so as not to lose time with secondary indicators, and it's recommended to apply this model to evaluate and to assess heritage districts all over Egypt in order to ensure the protection of the heritage core zones through an approach of buffer zones protection.

\section{REFERENCES}

${ }^{1}$ Martin, O., Piatti, G., World Heritage and Buffer Zones, UNESCO, 2009, page 17

${ }^{2}$ Alpopi, C., Manole, C., Integrated Urban Regeneration - Solution for Cities Revitalize,Elsevier, 2013, pages 178:185

3 Tournoux, M., Developing Historic Cities: A compilation of case studies on theconservation and management of historic cities, UNESCO, 2009, page 25

${ }^{4}$ World Heritage Center (WHC), Operational Guidelines, versions 1977, 1978, UNESCO

${ }^{5}$ World Heritage Center (WHC), Operational Guidelines, versions 1980, 1983, 1984 and 1987, UNESCO

${ }^{6}$ World Heritage Center (WHC), Operational Guidelines, versions1988, 1992, 1994 and1999, UNESCO 
${ }^{7}$ World Heritage Center (WHC), Operational Guidelines, version 2004, UNESCO

${ }^{8}$ World Heritage Center (WHC), Operational Guidelines, versions 2005 and 2008, UNESCO

${ }^{9}$ Abdullah, J. et al, Stakeholders perspectives of criteria for delineation of buffer Zone atConservation Reserve: FRIM heritage site, Elsevier, 2013, pages $610: 618$

${ }^{10}$ Egyptian government, Law of Antiquities 117 year 1983, Al Amiriah Press, 1983

${ }^{11}$ Egyptian government, Modification of law 117 in 2010, Al Amiriah Press, 2010

${ }^{12}$ World Heritage Center (WHC), Partnership for world heritage cities, UNESCO, 2003,pages 44:53

${ }^{13}$ World Heritage Center (WHC), Managing historic cities, UNESCO, 2010, page 46

${ }^{14}$ International Council on Monuments and Sites (ICOMOS), X'ian Declaration, 2005

${ }^{15}$ World Heritage Center (WHC), Operational Guidelines, version 2005, UNESCO, page 37

${ }^{16}$ UNESCO/ICCROM/ICOMOS/IUCN, Managing cultural world heritage, 2013, pages 8 , 64,80

${ }^{17}$ Worthing, D., Bond, S., Managing built heritage, Blackwell Publishing, 2008, page 42

${ }^{18}$ Wang, J., Problems and Solutions in the protection of historical urban area, Elsevier, 2011,page 41

${ }^{19}$ Previous reference, page 42

${ }^{20}$ Samadi, Z., Spirit of outdoor spaces in between urban heritage buildings, Elsevier, 2012,pages 460: 465

${ }^{21}$ Hussieny, A., Integration of Static and Dynamic Spaces in Historic Cairo: A communityspirit that may vanish, Elsevier, 2012, pages 687 :699

${ }^{22}$ Ismail, W., Contemporary Uses of Buildings on a Heritage Street, Elsevier, 2015, pages633: 641

${ }^{23}$ International Council on Monuments and Sites (ICOMOS), Threats to world heritage sites, 1994 - 2004:an analysis, 2005, pages 7and 8

${ }^{24}$ Martin, O., Piatti, G., World Heritage and Buffer Zones, UNESCO, 2009

${ }^{25}$ Previous reference 